\title{
Transcriptional Regulation of Hydrogen Peroxide and Calcium for Signaling Transduction and Stress- defensive Genes Contributing to Improved Drought Tolerance in Creeping Bentgrass
}

\author{
Zhou Li \\ Department of Grassland Science, College of Animal Science and Technology, Sichuan Agricultural \\ University, Chengdu 611130, Sichuan, China; and Department of Plant Biology, Rutgers University, \\ 59 Dudley Road, New Brunswick, NJ 08901 \\ Yan Peng \\ Department of Grassland Science, College of Animal Science and Technology, Sichuan Agricultural \\ University, Chengdu 611130, Sichuan, China \\ Bingru Huang \\ Department of Plant Biology, Rutgers University, 59 Dudley Road, New Brunswick, NJ 08901
}

\begin{abstract}
Additional index words. Agrostis stolonifera, antioxidant, Ca, dehydrins, fatty acid, $\mathrm{H}_{2} \mathrm{O}_{2}$, heat shock protein, metallothionein, transcription factor

Abstract. Small molecules, including $\mathrm{H}_{2} \mathrm{O}_{2}$ and $\mathrm{Ca}$, mediate stress signaling and drought tolerance in plants. The objective of this study was to determine whether improvement in drought tolerance by $\mathrm{H}_{2} \mathrm{O}_{2}$ and Ca were associated with the regulation of transcription factors and stress-protective genes in perennial grass species. Plants of creeping bentgrass (Agrostis stolonifera) were sprayed with water (control), $\mathrm{H}_{2} \mathrm{O}_{2}(9 \mathrm{~mm})$, or $\mathrm{CaCl}_{2}(10 \mathrm{~mm})$ and exposed to drought stress for 20 days in controlled-environment growth chambers. Foliar application of $\mathrm{H}_{2} \mathrm{O}_{2}$ or $\mathrm{Ca}$ led to significant improvement in drought tolerance of creeping bentgrass, as demonstrated by greater turf quality, leaf relative water content, chlorophyll content, photochemical efficiency, and cell membrane stability, as compared with the untreated control. The application of $\mathrm{H}_{2} \mathrm{O}_{2}$ and Ca resulted in significant up-regulation of genes in Ca signaling transduction pathways [Ca-dependent kinase 26 (CDPK26), mitogen-activated protein kinase 1 (MAPK1), and 14-3-3] and transcript factors (WRKY75 and $M Y B 13)$. For genes encoding antioxidant enzymes, $\mathrm{H}_{2} \mathrm{O}_{2}$ mainly enhanced superoxide dismutase $(S O D)$, catalase $(C A T)$, glutathione reductase $(G R)$, and dehydroascorbate reductase $(D H A R)$ expression, while Ca primarily improved transcript levels of $S O D$, monodehydroascorbate reductase (MDHAR), and GR. In addition, heat shock protein 70 (HSP70), metallothionein 1 (MT1), and glutamine synthetase 2 (GS2) were also markedly up-regulated by $\mathrm{H}_{2} \mathrm{O}_{2}$ and Ca under drought stress. However, the transcript level of lipoxygenase 3 (LOX3) was significantly down-regulated by $\mathrm{H}_{2} \mathrm{O}_{2}$ and $\mathrm{Ca}$ under well-watered and drought conditions. These results imply that $\mathrm{H}_{2} \mathrm{O}_{2}$ and $\mathrm{Ca}$ commonly or differentially regulate genes expression in association with drought tolerance through activating $\mathrm{Ca}$ signaling pathway and regulating transcription factors and stress-protective genes expression, leading to the alleviation of lipid peroxidation, maintenance of correct protein folding and translocation, and enhancement of nitrogen metabolism under a prolonged period of drought stress in creeping bentgrass.
\end{abstract}

Plant responses to drought stress involve multiple mechanisms at molecular, biochemical, physiological, and metabolic levels (Bhargava and Sawant, 2013; Shanker et al., 2014; Todaka et al., 2015). Many small molecules, such as $\mathrm{Ca}$ and $\mathrm{H}_{2}$ $\mathrm{O}_{2}$, play important roles in stress signaling and responses in plants (Apel and Hirt, 2004; Ermak and Davies, 2002; Reddy et al., 2011). Calcium could serve as an inorganic osmolyte for maintaining cell osmotic potential or signaling molecule for stress signal transduction in plants under abiotic stress, such as drought, high temperature, or salt stress (Bush, 1995). The

Received for publication 24 Jan. 2020. Accepted for publication 18 Mar. 2020. Published online 22 April 2020.

This research was supported by Sichuan Science and Technology Program (Grant No. 2017HH0060) and the Center for Turfgrass Science at Rutgers University.

B.H. is the corresponding author. E-mail: huang@sebs.rutgers.edu.

This is an open access article distributed under the CC BY-NC-ND license (https://creativecommons.org/licenses/by-nc-nd/4.0/). study of Jiang and Huang (2001) found that exogenous Ca application increased $\mathrm{Ca}$ concentration in cell saps contributing to improved osmotic adjustment and enhanced antioxidant capacity in two cool-season grass species under heat stress. Stress-triggered change of cytosolic $\mathrm{Ca}^{2+}$ in guard cells was correlated with stomatal closure, indicating the importance of $\mathrm{Ca}^{2+}$ signaling in drought responses ( $\mathrm{Fu}$ and $\left.\mathrm{Lu}, 2007\right)$. It has been found that exogenously applied $\mathrm{Ca}$ altered some antioxidant enzyme activities and enhanced root activity as well as the accumulation of osmolytes, which could improve drought tolerance of white clover (Trifolium repens), wheat (Triticum aestivum), and maize (Zea mays) (Li et al., 2015; Nayyar, 2003; Wang, 2010). Foliar Ca spray also effectively alleviated drought-induced growth inhibition, photoinhibition, and decline in leaf water in maize and sugar beet [Beta vulgaris (Hosseini et al., 2019; Naeem et al., 2018)]. These findings indicate positive function of $\mathrm{Ca}$ on improving drought tolerance involved in multiple physiological changes in plants. 
The higher concentration of $\mathrm{H}_{2} \mathrm{O}_{2}$ can cause lipid peroxidation, proteins degradation, accelerated senescence, and even programmed cell death, whereas the lower level and rapidly alteration of $\mathrm{H}_{2} \mathrm{O}_{2}$ acts as critical regulatory roles in intermediate signaling transduction for activation of defense mechanisms in plants during early phases of stress responses (Ray et al., 2012; Suzuki et al., 2012; Yu, 1994). Previous studies demonstrated that exogenous $\mathrm{H}_{2} \mathrm{O}_{2}$ enhanced heat tolerance through improving cell membrane stability, leaf photosynthesis, and antioxidant enzyme activities in creeping bentgrass [Agrostis stolonifera (Larkindale and Huang, 2004, 2005)]. The appropriate low concentration of foliar $\mathrm{H}_{2} \mathrm{O}_{2}$ application alleviated drought damage in soybean (Glycine max) and marigold (Tagetes erecta) associated with carbohydrate accumulation and roots development (Ishibashi et al., 2011; Liao et al., 2012). Abscisic acid (ABA) triggered $\mathrm{H}_{2} \mathrm{O}_{2}$ signaling to induce antioxidant defense, thereby alleviating drought-caused oxidative damage in bermudagrass [Cynodon dactylon ( $\mathrm{Lu}$ et al., 2009)]. It has been widely reported that both of $\mathrm{H}_{2} \mathrm{O}_{2}$ and $\mathrm{Ca}^{2+}$ could regulate stress-related downstream genes expression associated with improved drought tolerance in different plant species $(\mathrm{Li}$ et al., 2015; Neill et al., 2002; Xu et al., 2015; You et al., 2013). However, $\mathrm{H}_{2} \mathrm{O}_{2}$ - and Ca-regulated signaling transduction, and key genes controlling drought tolerance were not well documented in plants exposed to severe or a prolonged period of drought stress.

Objectives of this study were to 1) assess effects of $\mathrm{H}_{2} \mathrm{O}_{2}$ and $\mathrm{Ca}$ signaling molecules on improving drought tolerance through physiological analysis; and 2) examine genes transcript level encoding signaling transduction, transcription factors, antioxidant enzymes, and stress-related proteins that may be commonly or differentially regulated by $\mathrm{H}_{2} \mathrm{O}_{2}$ and $\mathrm{Ca}$ associated with drought tolerance in creeping bentgrass under a prolonged drought stress.

\section{Materials and Methods}

Plant material and treatment. Creeping bentgrass ('Penncross') sod plugs ( $5 \mathrm{~cm}$ diameter) were collected from Rutgers University Horticultural Farm II (North Brunswick, $\mathrm{NJ})$ and planted in plastic containers $(40 \mathrm{~cm}$ length, $30 \mathrm{~cm}$ width, and $35 \mathrm{~cm}$ height). A total of eight containers were used, and each container includes three sod plugs. Fritted clay was used as soil matrix, and all containers were placed in a greenhouse [average $23 / 18{ }^{\circ} \mathrm{C}$ of day/night, $790 \mu \mathrm{mol} \cdot \mathrm{m}^{-2} \cdot \mathrm{s}^{-1}$ photosynthetically active radiation $(P A R)]$. Plants were trimmed to maintain a canopy height of $3 \mathrm{~cm}$ and irrigated twice per week with Hoagland's solution (Hogland and Arnon, 1950) for 2 months in the greenhouse during SeptemberOctober. Plants were then moved to controlled growth chambers (Environmental Growth Chamber, Chagrin Falls, $\mathrm{OH}$ ) that provided $21 / 19^{\circ} \mathrm{C}$ (day/night), $70 \%$ relative humidity, and 12 -h photoperiod at $660 \mu \mathrm{mol} \cdot \mathrm{m}^{-2} \cdot \mathrm{s}^{-1} P A R$. After acclimation in the growth chamber for 1 week, each sod plug was sprayed with $10 \mathrm{~mL}$ of $9 \mathrm{~mm} \mathrm{H}_{2} \mathrm{O}_{2}$ or $10 \mathrm{~mm} \mathrm{CaCl}_{2}$ solution or distilled water (untreated control) once each day for $3 \mathrm{~d}$. After pretreatments, plants were cultivated under the well-watered condition (plants were irrigated every $2 \mathrm{~d}$ and soil water content was maintained at the pot capacity) or exposed to drought stress (stopping irrigating) for $20 \mathrm{~d}$ during the month of November. The concentration of $\mathrm{H}_{2} \mathrm{O}_{2}$ and $\mathrm{CaCl}_{2}$ were selected based on a preliminary experiment. Each treatment has four replications in four different containers that were placed in four growth chambers. Leaf samples were collected from plants at $20 \mathrm{~d}$ of drought stress treatment.

Measurements of turf Quality and Physiological PARAMETERs. Turf quality (TQ) was evaluated by using a scale of 1 to 9 according to color, density, and uniformity of turfgrass (Beard, 2001). Leaf relative water content (RWC) or electrolyte leakage (EL) was detected by using the method of Barrs and Weatherley (1962) or Blum and Ebercon (1981), respectively. Assay methods in details were recorded in our previous study (Li et al., 2016a). For chlorophyll (Chl) content, $0.1 \mathrm{~g}$ of fresh leaves were cut from plants and submerged in $10 \mathrm{~mL}$ of dimethyl sulphoxide. After being placed in the dark for $48 \mathrm{~h}$, leaves extractions were measured at 663 and $645 \mathrm{~nm}$ using a spectrophotometer (Spectronic Instruments, Rochester, NY) (Arnon, 1949). For photochemical efficiency (Fv/Fm), leaves were pretreated into darkness through leaf clips for $20 \mathrm{~min}$. Fv/ Fm ratio was then recorded by using a fluorescence meter (Fim 1500; Dynamax, Houston, TX).

GENE EXPRESSION ANALYSIS. For genes expression analysis, real-time quantitative polymerase chain reaction (qRT-PCR) was used. RNeasy Mini Kit (Qiagen, Duesseldorf, Germany) was used for extracting total RNAs in fresh leaves according to manufacturer's instructions. The RNA was then reverse-transcribed into cDNA (A revert Aid First Stand cDNA Synthesis Kit; Fermentas, Burlington, ON, Canada). For the PCR protocol, the conditions were set: $5 \mathrm{~min}$ at $95^{\circ} \mathrm{C}$, and 40 repeats of denaturation at $95{ }^{\circ} \mathrm{C}$ for $15 \mathrm{~s}$, annealing at $60{ }^{\circ} \mathrm{C}$ for $45 \mathrm{~s}$, followed by heating the amplicon from 60 to $95^{\circ} \mathrm{C}$ to obtain the melting curve. The Eq. The formula $2^{-\Delta \Delta \mathrm{Ct}}$ was used for calculating the transcript level of all genes (Xia et al., 2009). Table 1 shows primer sequences of all genes, including reference gene $A C T 2$.

Statistical analysis. Experiment design was a split-plot design with water status as the main plot and small molecules $\left(\mathrm{H}_{2} \mathrm{O}, \mathrm{Ca}\right.$, and $\left.\mathrm{H}_{2} \mathrm{O}_{2}\right)$ treatments as the sub-plot. Data were analyzed by using the general linear model procedure for the analysis of variance (SAS version 9.1; SAS Institute, Cary, NC). The significance of differences was tested by using Fisher's protected least significance test with $P \leq 0.05$.

\section{Results}

Physiological responses to $\mathrm{H}_{2} \mathrm{O}_{2}$ and $\mathrm{C}_{\text {a }}$ in CReeping BeNTGRASS. $\mathrm{H}_{2} \mathrm{O}_{2}$ and $\mathrm{Ca}$ application had no significant effects on TQ, RWC, EL, Chl, and Fv/Fm in leaves under well-watered condition. Drought stress significantly decreased TQ, RWC, $\mathrm{Chl}$ content, and $\mathrm{Fv} / \mathrm{Fm}$ ratio, but increased EL of leaves (Figs. 1 and 2). Under drought stress, $\mathrm{H}_{2} \mathrm{O}_{2}$ - and Ca-treated plants exhibited significantly higher TQ and RWC and lower EL than nontreated plants (Fig. 1). Both $\mathrm{H}_{2} \mathrm{O}_{2}$ - and Ca-treated plants maintained a $30 \%$ increase in $\mathrm{Chl}$ content compared with nontreated plants in response to drought stress, and $\mathrm{Fv} / \mathrm{Fm}$ ratio was also significantly higher in $\mathrm{H}_{2} \mathrm{O}_{2^{-}}$and Ca-treated plants than that in nontreated plants under drought stress (Fig. 2).

EXPRESSION OF GENES INVOLVED IN SIGNALING TRANSDUCTION AND TRANSCRIPTION FACTORS BY $\mathbf{H}_{2} \mathrm{O}_{2}$ AND CA. In response to drought stress, most of genes expression levels were affected by $\mathrm{H}_{2} \mathrm{O}_{2}$ and $\mathrm{Ca}^{2+}$ (Fig. 3A). $\mathrm{H}_{2} \mathrm{O}_{2}$ and $\mathrm{Ca}$ induced significant changes in five genes, while four genes were only regulated by $\mathrm{Ca}$ under well-watered conditions (Fig. 3B). Twelve genes 
Table 1. Primer sequences used for detecting transcript levels of genes in real-time quantitative polymerase chain reaction (qRT-PCR) and their corresponding GeneBank accession numbers of the analyzed genes.

\begin{tabular}{|c|c|c|c|}
\hline Target gene ${ }^{\mathrm{z}}$ & Accession no. & Forward primer $\left(5^{\prime}-3^{\prime}\right)$ & Reverse primer $\left(5^{\prime}-3^{\prime}\right)$ \\
\hline$C D P K 26$ & GR281936.1 & ATCCAGGCTGCTCACTCCGTA & AACCAACGCAGGGTAGGATTTC \\
\hline$M A P K 1$ & DV866362.1 & AGCTGGCCCTGCATGGATAA & CAGGACAATGTTCAGATGGAGGC \\
\hline $14-3-3$ & DV866921.1 & TCATGGACAAGATCAAGGAGAAG & CAAACACCCAAGTGAGCTAAAC \\
\hline$A B F 3$ & DV862003.1 & ATCTGCCTGCGGAGGACACT & TGAAGCATCGGAACAGTGGC \\
\hline WRKY75 & DV867719.1 & TGGTGGTGACGACATACGAGG & GGTTGGTAAAGGTTGAGGAGGTG \\
\hline MYB13 & GR279830.1 & CATTCAGTTTACCCGAGTGCG & CATAAAACATGACCCATCACAGCT \\
\hline$S O D$ & DV867103 & CACTGGACCTCACTTCAAC & GTAGCAACACCATCCACTC \\
\hline$C A T$ & DY543619 & TTGCCAATAAGAGGGAGAATG & CGAAGCCGAGCATGTAAG \\
\hline$A P X$ & GR281667 & AGGACATTGTTGCCCTTTC & GCTCCGTGAAGTAAGAGTTG \\
\hline$M D H A R$ & DV865007 & CCATGAAGCTCTACAACGAG & GTAGAAGTAGGGCAGGTAGT \\
\hline$D H A R$ & DV853556 & GAAAGGTGCCTGTGTTTAATG & GTGATGGAGTTGGGTACTTC \\
\hline$G R$ & AB277097 & GATGGAGGCTACTTGCTTTG & GCTAAGACCCACGACAGATA \\
\hline HSP70 & DV860338.1 & CCTGCCCAATTTGCATTACC & CAGACGGAGAAGCAACTGAA \\
\hline HSP90 & GR280041.1 & CCACCCATACTCACCTGTCACG & CAAGGAGAAGTTTGAAGGGCTATG \\
\hline DHN3 & FE527922.1 & CATGGCGTCTACTGCTTGTA & CAGAGGACTTGAACCCAGATAC \\
\hline MT1 & DV865927.1 & TCTCCAAGCTCATCTTCTTCTCATT & TTCGTCCAGGTCAGGGTACATC \\
\hline GS2 & DV862105.1 & GCTGGCGATGAACGTATGAAG & ACAGACAGTGCCCTGACGGA \\
\hline$L O X 3$ & GR279465.1 & AGGGCTGGTCCTTGATGTCG & TCTACTACCCCAGCGACAGCAT \\
\hline$A C T 2$ & DY543529 & CCTTTTCCAGCCATCTTTCA & GAGGTCCTTCCTGATATCCA \\
\hline
\end{tabular}

${ }^{\mathrm{z}} A B F 3=A B R E$ binding factor $3, A C T 2=$ actin $2, A P X=$ ascorbate peroxidase, $C A T=$ catalase, $C D P K 26=C a-d e p e n d e n t ~ k i n a s e ~ 26, D H A R=$ dehydroascorbate reductase, $D H N 3=$ dehydrin $3, G R=$ glutathione reductase, $G S 2=$ glutamine synthetase $2, H S P 70=$ heat shock protein 70 , $H S P 90=$ heat shock protein 90, LOX3 = lipoxygenase 3, MAPK1 = mitogen-activated protein kinase 1, MSHAR = monodehydroascorbate reductase, $M T 1=$ metallothionein 1, MYB13 = MYB transcription factor 13, SOD = superoxide dismutase, WRKY75=WRKY transcription factor 75 .

were affected by both $\mathrm{H}_{2} \mathrm{O}_{2}$ and $\mathrm{Ca}$, and two genes were specifically regulated by $\mathrm{H}_{2} \mathrm{O}_{2}$ under drought stress. Only one gene was specifically induced by $\mathrm{Ca}$ under drought stress (Fig. 3C). Under well-watered conditions, foliar spraying with $\mathrm{Ca}$ upregulated the expression levels of CDPK26, MAPK1, and $M Y B 13$, and the application of $\mathrm{H}_{2} \mathrm{O}_{2}$ only upregulated MAPK1 expression compared with the well-watered control (Figs. 4 and 5). Drought stress induced significant increases in $C D P K 26$, MAPK1, 14-3-3, ABF3, WRKY75, and MYB13 transcript levels with or without $\mathrm{H}_{2} \mathrm{O}_{2}$ and $\mathrm{Ca}$ application (Figs. 4 and 5). Under drought stress, both $\mathrm{H}_{2} \mathrm{O}_{2}$ - and Ca-treated plants showed 4-fold increases in CDPK26 and 14-3-3 as well as 5-fold increase in $M A P K 1$ expression level compared with nontreated plants (Fig. 4). For transcription factors, there was six times as high WRKY75 and MYB13 transcript levels in $\mathrm{H}_{2} \mathrm{O}_{2}$-treated plants as in nontreated plants under drought conditions (Fig. 5B and C). Similarly, WRKY75 and MYB13 transcript levels of Catreated plants were three times significantly higher than that of nontreated plants under drought stress (Fig. 5B and C). However, $\mathrm{H}_{2} \mathrm{O}_{2}$ and $\mathrm{Ca}$ had no effect on the transcript level of $A B F 3$ under well-watered and drought conditions (Fig. 5A).

EXPRESSION OF GENES INVOLVED IN ANTIOXIDANT DEFENSE AFFECTED BY $\mathrm{H}_{2} \mathrm{O}_{2}$ AND CA. Exogenous application of $\mathrm{H}_{2} \mathrm{O}_{2}$ and $\mathrm{Ca}$ significantly upregulated $C A T, M D H A R$, and $G R$ transcript levels under well-watered conditions (Fig. 6B, D, and F). Under drought conditions, $S O D$ was upregulated by exogenous $\mathrm{H}_{2} \mathrm{O}_{2}$ and $\mathrm{Ca}$ (Fig. 6A). Exogenous $\mathrm{H}_{2} \mathrm{O}_{2}$ application upregulated $C A T$ and $D H A R$, but $\mathrm{Ca}$ had no significant effects on these two genes under drought stress (Fig. 6B and E). Neither $\mathrm{H}_{2} \mathrm{O}_{2}$ nor $\mathrm{Ca}$ application had significant effects on the expression of ascorbate peroxidase $(A P X)$ under well-watered or drought conditions (Fig. 6C). However, exogenous $\mathrm{Ca}$ upregulated MDHAR expression under drought stress, and the increased percentage was $114 \%$ (Fig. 6D). GR transcript level in $\mathrm{H}_{2} \mathrm{O}_{2}-$ and Ca-treated plants was significantly higher than that in nontreated plants by two times under drought stress (Fig. 6F).

EXPRESSION OF GENES INVOLVED IN STRESS-PROTECTIVE PROTEINS AND OTHER METABOLISM AFFECTED BY $\mathrm{H}_{2} \mathrm{O}_{2}$ AND CA. Under well-watered condition, heat shock protein 90 (HSP90) and $M T 1$ expression were not changed by foliar application of $\mathrm{H}_{2} \mathrm{O}_{2}$ and $\mathrm{Ca}$, and exogenous $\mathrm{H}_{2} \mathrm{O}_{2}$ upregulated $H S P 70$ and dehydrin 3 (DHN3); but Ca did not show significant effects on HSP70 and DHN3 expression level (Fig. 7). Under drought stress, $H S P 70$ expression level of $\mathrm{H}_{2} \mathrm{O}_{2}$ - and Ca-treated plants increased by $60 \%$ compared with nontreated plants, and $\mathrm{H}_{2} \mathrm{O}_{2}-$ and Ca-treated plants also had 3-fold increases in MT1 transcript level compared with nontreated plants; but $H S P 90$ expression was unaffected by exogenous application of $\mathrm{H}_{2} \mathrm{O}_{2}$ and $\mathrm{Ca}$ (Fig. 7A and D). Drought stress induced more than 500 times increase in DHN3 in all treatments relative to wellwatered plants, but drought-stressed plants treated with $\mathrm{H}_{2} \mathrm{O}_{2}$ and $\mathrm{Ca}$ exhibited significantly lower $\mathrm{DHN} 3$ expression than drought-stressed plants without chemical treatment (Fig. 7C). Foliar application of $\mathrm{H}_{2} \mathrm{O}_{2}$ and $\mathrm{Ca}$ had no significant effects on GS2 expression, whereas $L O X 3$ was significantly downregulated by $\mathrm{H}_{2} \mathrm{O}_{2}$ under well-watered condition (Fig. 8). Under drought stress, the GS2 transcript level in $\mathrm{H}_{2} \mathrm{O}_{2}$ - and Ca-treated plants had three times increase compared with drought-stressed control plants (Fig. 8A). On the contrary, $L O X 3$ expression was significantly inhibited by $\mathrm{H}_{2} \mathrm{O}_{2}$ and $\mathrm{Ca}$ under well-watered and drought conditions (Fig. 8B).

\section{Discussion}

Plant tolerance to drought stress involves the activation of stress signaling transduction pathways, which include multiple 

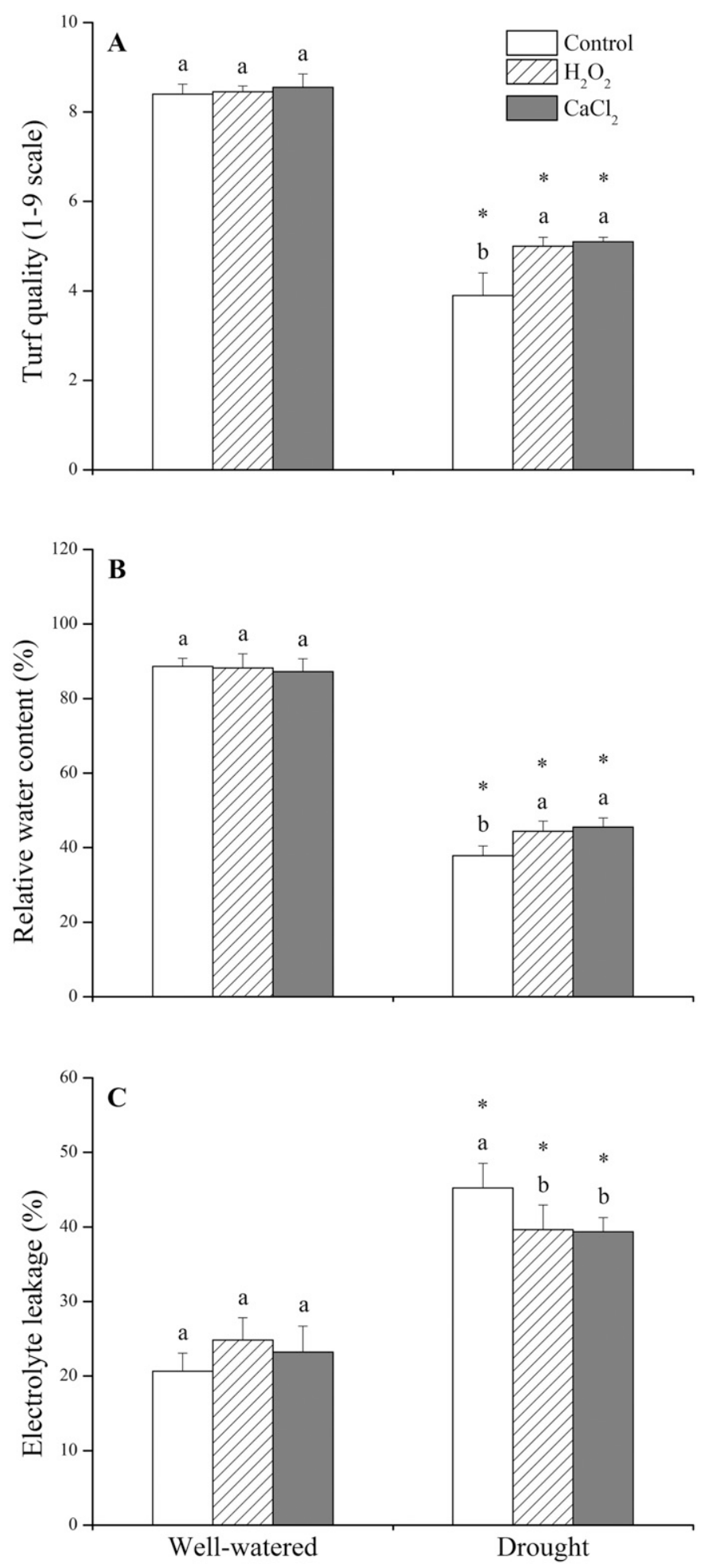

Fig. 1. Effects of $\mathrm{H}_{2} \mathrm{O}_{2}$ and $\mathrm{CaCl}_{2}$ on (A) turf quality, (B) relative water content, and (C) electrolyte leakage in creeping bentgrass under well-watered and drought condition for $20 \mathrm{~d}$. Vertical bars indicate $\pm \mathrm{SE}(\mathrm{n}=4)$. Different letters above columns indicate significant differences among control, $\mathrm{H}_{2} \mathrm{O}_{2}$, and $\mathrm{Ca}$ treatment under a given condition (well-watered or drought); asterisk (*) indicates significant difference for one particular treatment (control, $\mathrm{H}_{2} \mathrm{O}_{2}$, or $\mathrm{Ca}$ ) between well-watered and drought condition.

transcriptional factors or genes (Dortje et al., 2011). CDPK and $M A P K$ are two critical kinases involved in $\mathrm{Ca}^{2+}$ signaling transduction pathways (Anil and Rao, 2001). CDPK and MAPK signaling transduction regulate transcription factors such as
$W R K Y$ and $M Y B$ families, which play critical roles in drought tolerance in plants via the activation of downstream signaling and stress-defensive genes (Boudsocq and Sheen, 2013; Chen et al., 2012; Danquah et al., 2014; Singh et al., 2002). Previous studies have proved that $\mathrm{Ca}^{2+}$ and reactive oxygen species (ROS) signaling are integrated in cells in most of cases. $\mathrm{Ca}^{2+}$ channels could be activated by $\mathrm{H}_{2} \mathrm{O}_{2}$, and ROS signaling production also could be directly regulated by $\mathrm{Ca}^{2+}$ signaling under normal and abiotic stress conditions (Camello-Almaraz et al., 2006; Gilroy et al., 2014; Pei et al., 2000). The research of $\mathrm{Li}$ et al. (2015) indicated that $\mathrm{H}_{2} \mathrm{O}_{2}$ interacting with $\mathrm{Ca}^{2+}$ signaling were involved in polyamine-regulated drought tolerance in white clover though activating $C D P K$ signaling. The 14-3-3 proteins are important conserved signaling proteins involved in cellular signaling transduction and also have major regulatory function of carbohydrate and nitrogen metabolism in plants (Comparot et al., 2003; Roberts et al., 2002). In addition, 14-3-3 proteins also could regulate multiple signal transduction proteins such as $C D P K$ in response to environmental stresses in higher plants (Roberts et al., 2002). Previous studies indicated that 14-3-3 protein or genes could be differentially mediated by salinity, drought, and cold, which is an important part of stress defense signaling in plants (Chen et al., 1994; Chen et al., 2006; Jarillo et al., 1994). It has been reported that overexpressing a tomato 14-3-3 gene enhanced salt tolerance in Arabidopsis thaliana (Xu and Shi, 2007). A "stay-green" phenotype and better drought tolerance were observed in transgenic cotton overexpressing a 14-3-3 gene (Yan et al., 2004). In this study, the application of $\mathrm{H}_{2} \mathrm{O}_{2}$ and $\mathrm{Ca}$ up-regulated 14-3-3, CDPK26, MAPK1, WRKY75, and MYB13 in creeping bentgrass exposed to drought stress. Our results, together with reports in previous studies, suggest that $\mathrm{H}_{2} \mathrm{O}_{2}$ and $\mathrm{Ca}$ could regulate 14-3-3, CDPK26, MAPK1, WRKY75, and MYB13, which may contribute to improved drought tolerance due to the application of those two molecules in creeping bentgrass, as manifested by increased TQ, leaf RWC, Chl content, Fv/Fm, and cell membrane stability under drought stress.

In addition to transcriptional factors in signaling pathways, changes in downstream stress-protective genes also affect plant tolerance to drought stress (Shinozaki and Yamaguchi-Shinozaki, 2007). $\mathrm{H}_{2} \mathrm{O}_{2}$ and $\mathrm{Ca}$ up-regulated $H S P 70$ and $M T 1$ under drought stress in our study. HSPs are important molecular chaperones that help proteins to fold and assemble correctly related to plant adaption to abiotic stress (Sabehat et al., 1998; Sørensen et al., 2003; Wang et al., 2004). HSPs not only play positive roles in regulating heat tolerance, but also are correlated with the improvement of drought tolerance in plants. For example, the transgenic tobacco (Nicotiana tabacum) constitutively expressing a HSP70 obtained stress tolerance under progressive drought (Cho and Hong, 2006). MT1 gene regulates synthesis of metallothionein, which plays roles in stabilization of cellular membranes, antioxidant, and metal ion homeostasis (Ruttkay-Nedecky et al., 2013). Transgenic rice (Oryza sativa) overexpressing an OsMTla demonstrated the significant increase in drought tolerance associated with ROS scavenging and ions homeostasis (Yang et al., 2009). The improved accumulation of MT played an important role in spermidineregulated drought tolerance in white clover ( $\mathrm{Li}$ et al., 2016b). Current results suggest that $\mathrm{H}_{2} \mathrm{O}_{2}$ and Ca-regulated drought tolerance in creeping bentgrass could be associated with activation of HSP70 and MTI expression. DHNs encoding dedydrins are drought-inducible genes and their up-regulation may 

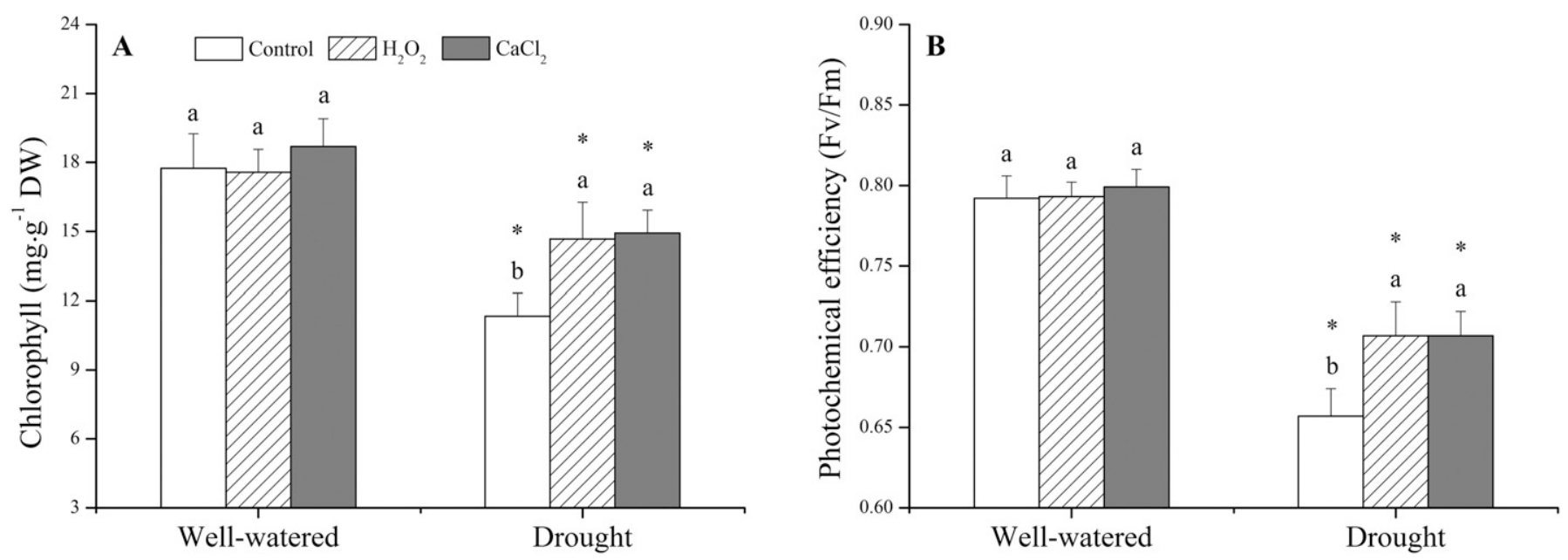

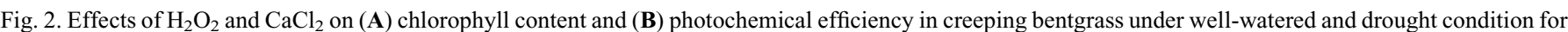
$20 \mathrm{~d}$. Vertical bars indicate \pm SE $(n=4)$. Different letters above columns indicate significant differences among control, $\mathrm{H}_{2} \mathrm{O}_{2}$, and $\mathrm{Ca}$ treatment under a given condition (well-watered or drought); asterisk (*) indicates significant difference for one particular treatment (control, $\mathrm{H}_{2} \mathrm{O}_{2}$, or Ca) between well-watered and drought condition.

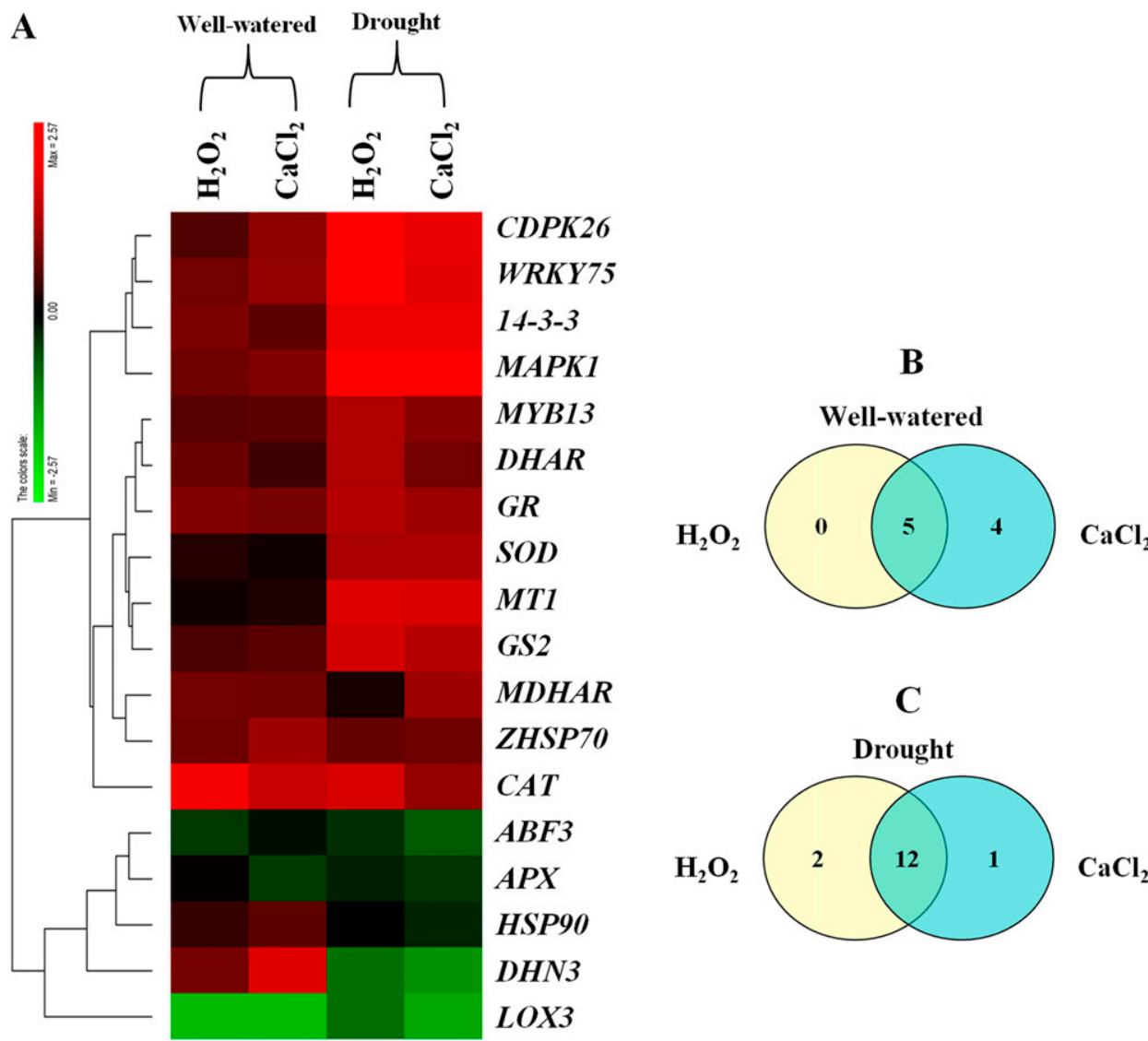

Fig. 3. (A) Heat map of changes in 18 genes expression levels in creeping bentgrass under well-watered and drought condition, (B) differential regulated genes induced by $\mathrm{H}_{2} \mathrm{O}_{2}$ and $\mathrm{CaCl}_{2}$ under well-watered condition, and (C) differential regulated genes induced by $\mathrm{H}_{2} \mathrm{O}_{2}$ and $\mathrm{CaCl}_{2}$ under drought condition in creeping bentgrass. The $\log _{2}$ fold change ratios are shown in the results. Red indicates an upregulation, and green indicates a downregulation.

drought stress, while $\mathrm{H}_{2} \mathrm{O}_{2}$ and $\mathrm{Ca}$ application suppressed the up-regulation of $\mathrm{DHN} 3$ under drought stress, indicating $\mathrm{H}_{2} \mathrm{O}_{2}$ - and Ca-treated plants might have suffered less stress damage.

Antioxidant defense is another stress-defense pathway including enzymatic and nonenzymatic components. Antioxidant enzymes function as scavengers of ROS in cells, thereby alleviating stress-induced oxidative damage (Hasanuzzaman et al., 2012). $\mathrm{H}_{2} \mathrm{O}_{2}$ and $\mathrm{Ca}$ act as mediators to participate in regulating antioxidant defense. For example, ABA triggered NADPH oxidase to release $\mathrm{H}_{2} \mathrm{O}_{2}$, resulting in the activation of $S O D, C A T$, and $A P X$ against oxidative damage in bermudagrass (Lu et al., 2009). Brassinosteroid-induced $\mathrm{H}_{2} \mathrm{O}_{2}$ accumulation was accompanied by increases in $S O D, C A T$, and key enzymes involved in an ascorbate-glutathione cycle leading to enhanced tolerance to oxidative stress in cucumber (Cucumis sativus) leaves (Xia et al., 2009). Polyamine could activate $\mathrm{H}_{2} \mathrm{O}_{2}$ and $\mathrm{Ca}$ signaling to regulate antioxidant enzyme activities and genes expression in white clover under water deficit condition ( $\mathrm{Li}$

protect cells from drought damages and may reflect the level of drought stress that the plant has experienced, depending on stress duration and severity (Hara, 2010). In our study, the transcript level of DHN3 increased by thousands of times in response to et al., 2015). Foliar applied Ca significantly increased $C A T$, $G R$, and $A P X$ activities associated with significant declines in membrane lipid peroxidation in two cool-season grasses, tall fescue (Festuca arundinacea) and kentucky bluegrass 

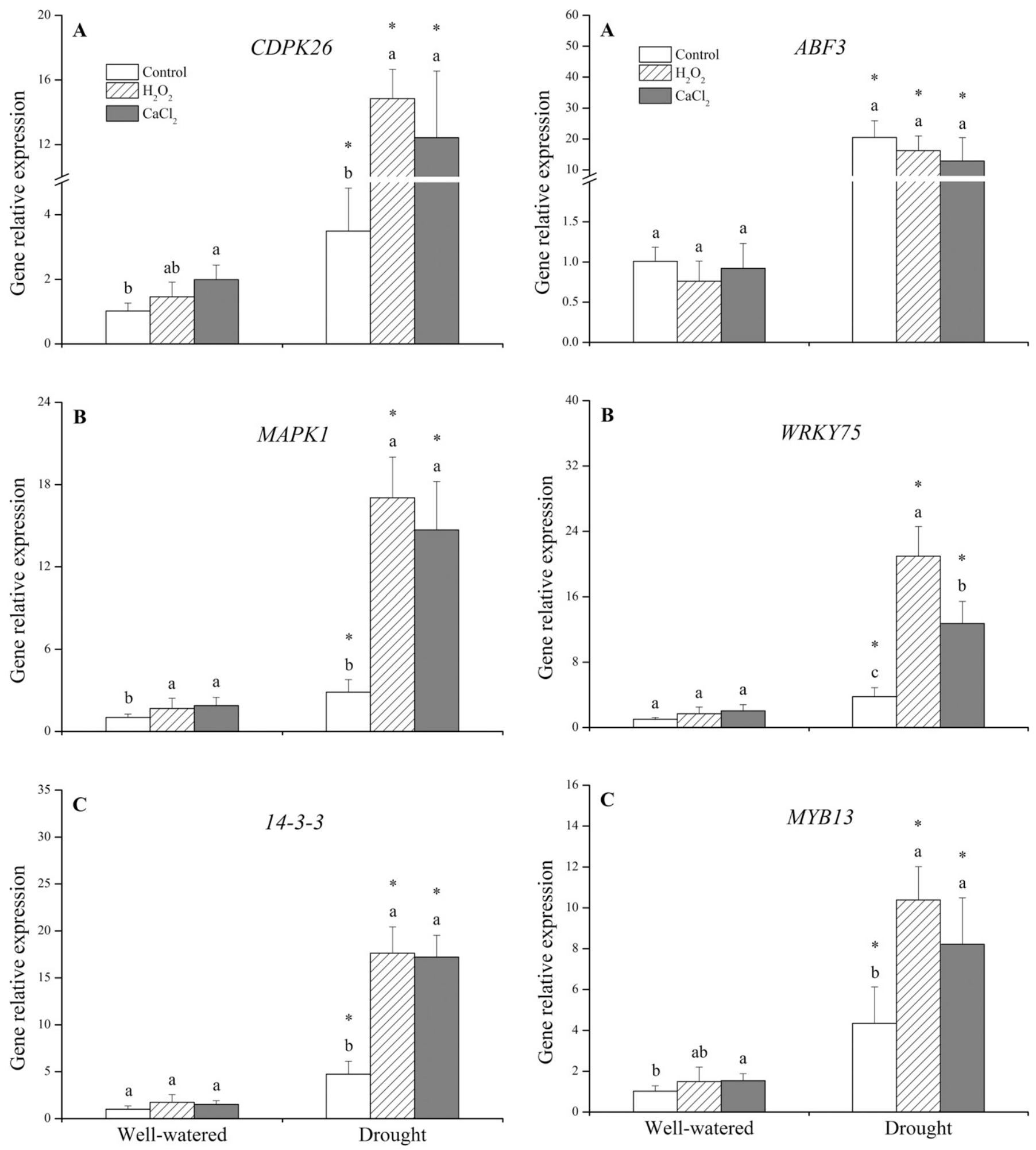

Fig. 4. Effects of $\mathrm{H}_{2} \mathrm{O}_{2}$ and $\mathrm{CaCl}_{2}$ on genes expression of (A) Ca-dependent kinase $26(C D P K 26),(\mathbf{B})$ mitogen-activated protein kinase 1 (MAPK1), and (C) 14-3-3 in creeping bentgrass under well-watered and drought condition for $20 \mathrm{~d}$. Vertical bars indicate $\pm \operatorname{SE}(\mathrm{n}=4)$. Different letters above columns indicate significant differences among control, $\mathrm{H}_{2} \mathrm{O}_{2}$, and $\mathrm{Ca}$ treatment under a given condition (well-watered or drought); asterisk $(*)$ indicates significant difference for one particular treatment (control, $\mathrm{H}_{2} \mathrm{O}_{2}$, or Ca) between wellwatered and drought condition.

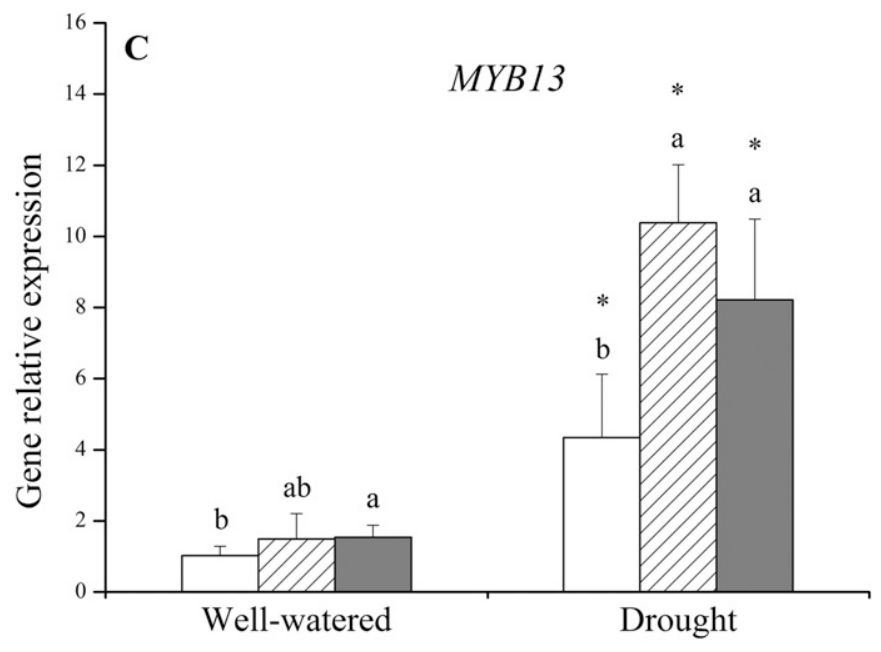

Fig. 5. Effects of $\mathrm{H}_{2} \mathrm{O}_{2}$ and $\mathrm{CaCl}_{2}$ on genes expression of transcription factors (A) ABRE binding factor 3 (ABF3), (B) WRKY transcription factor 75 (WRKY75), and (C) MYB transcription factor 13 (MYB13) in creeping bentgrass under well-watered and drought condition for $20 \mathrm{~d}$. Vertical bars indicate $\pm \operatorname{SE}(\mathrm{n}=4)$. Different letters above columns indicate significant differences among control, $\mathrm{H}_{2} \mathrm{O}_{2}$, and $\mathrm{Ca}$ treatment under a given condition (well-watered or drought); asterisk $(*)$ indicates significant difference for one particular treatment (control, $\mathrm{H}_{2} \mathrm{O}_{2}$, or Ca) between well-watered and drought condition. 

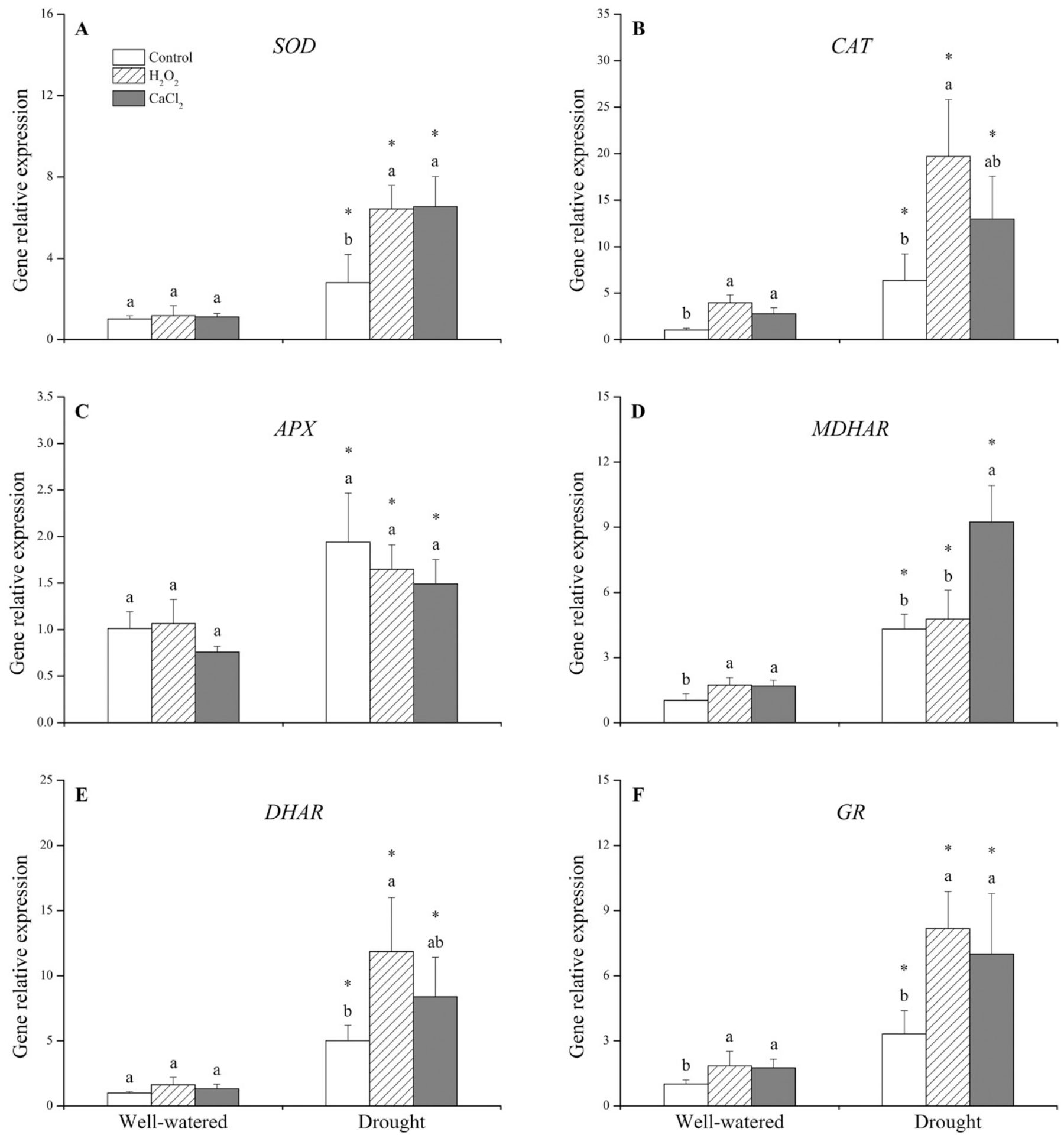

Fig. 6. Effects of $\mathrm{H}_{2} \mathrm{O}_{2}$ and $\mathrm{CaCl}_{2}$ on genes encoding antioxidant enzyme (A) superoxide dismutase $(S O D),(\mathbf{B})$ catalase $(C A T),(\mathbf{C})$ ascorbate peroxidase $(A P X)$, (D) monodehydroascorbate reductase $(M D H A R),(\mathbf{E})$ dehydroascorbate reductase $(D H A R)$, and (F) glutathione reductase $(G R)$ in creeping bentgrass under wellwatered and drought condition for $20 \mathrm{~d}$. Vertical bars indicate $\pm \mathrm{SE}(\mathrm{n}=4)$. Different letters above columns indicate significant differences among control, $\mathrm{H}_{2} \mathrm{O}_{2}$, and $\mathrm{Ca}$ treatment under a given condition (well-watered or drought); asterisk (*) indicates significant difference for one particular treatment $\left(\mathrm{control}, \mathrm{H}_{2} \mathrm{O}_{2}\right.$, or Ca) between well-watered and drought condition.

(Poa pratensis), under heat stress (Jiang and Huang, 2001). In this current study, SOD, CAT, DHAR, and GR were upregulated by $\mathrm{H}_{2} \mathrm{O}_{2}$, whereas $\mathrm{Ca}$ mainly induced $S O D$, $M D H A R$, and $G R$ expression under drought stress, which may contribute to improved drought tolerance; however, $\mathrm{H}_{2} \mathrm{O}_{2}$ and $\mathrm{Ca}$ regulated antioxidant defense through different enzymatic components in creeping bentgrass. In addition to ROS-induced oxidative damages, dioxygenation of polyun- 

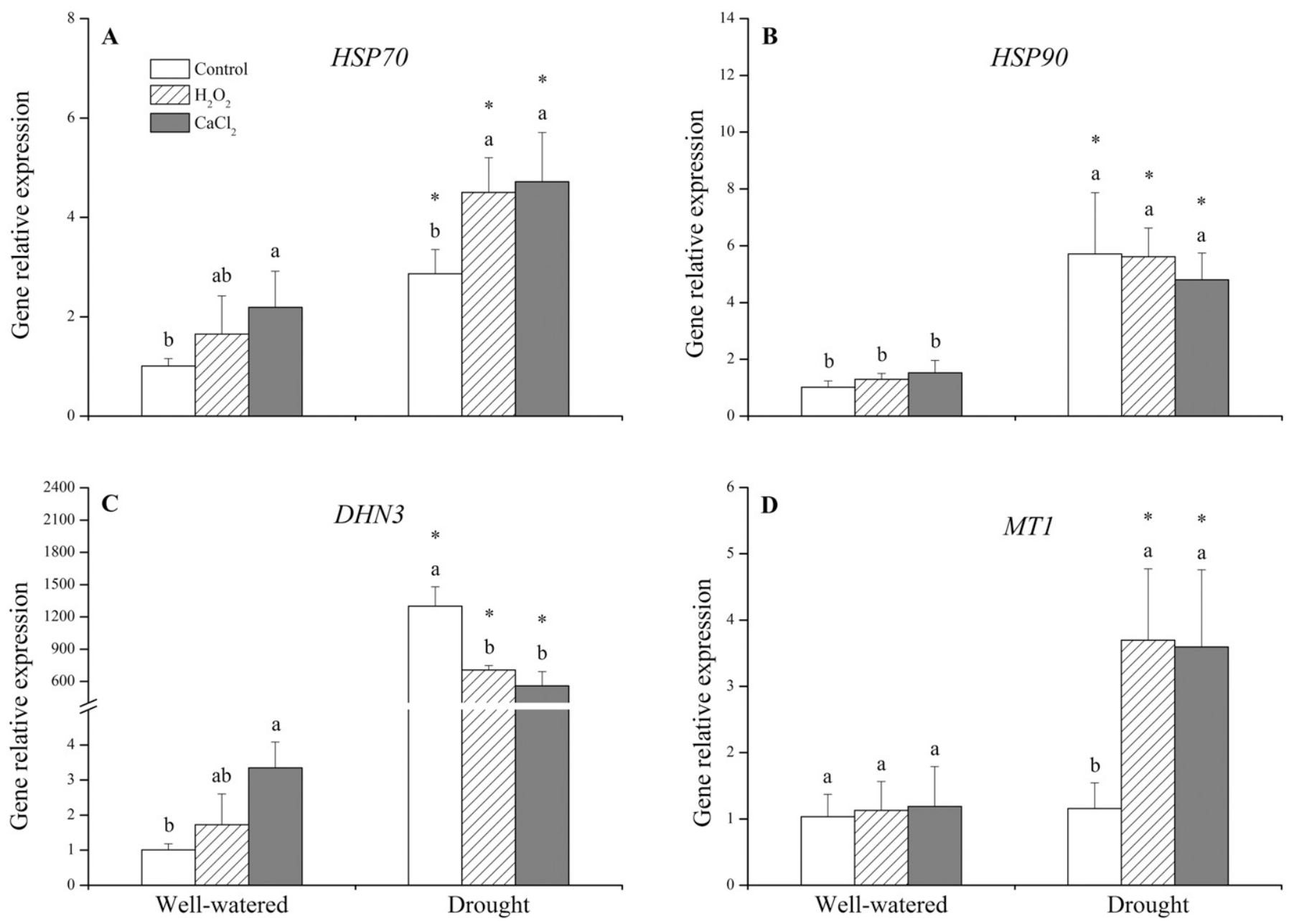

Fig. 7. Effects of $\mathrm{H}_{2} \mathrm{O}_{2}$ and $\mathrm{CaCl}_{2}$ on genes encoding stress-related proteins (A) heat shock protein 70 (HSP70), (B) heat shock protein 90 (HSP90), (C) dehydrin 3 (DHN3), and (D) metallothionein 1 (MTI) in creeping bentgrass under well-watered and drought condition for $20 \mathrm{~d}$. Vertical bars indicate $\pm \mathrm{SE}(\mathrm{n}=4)$. Different letters above columns indicate significant differences among control, $\mathrm{H}_{2} \mathrm{O}_{2}$, and Ca treatment under a given condition (well-watered or drought); asterisk (*) indicates significant difference for one particular treatment (control, $\mathrm{H}_{2} \mathrm{O}_{2}$, or Ca) between well-watered and drought condition.
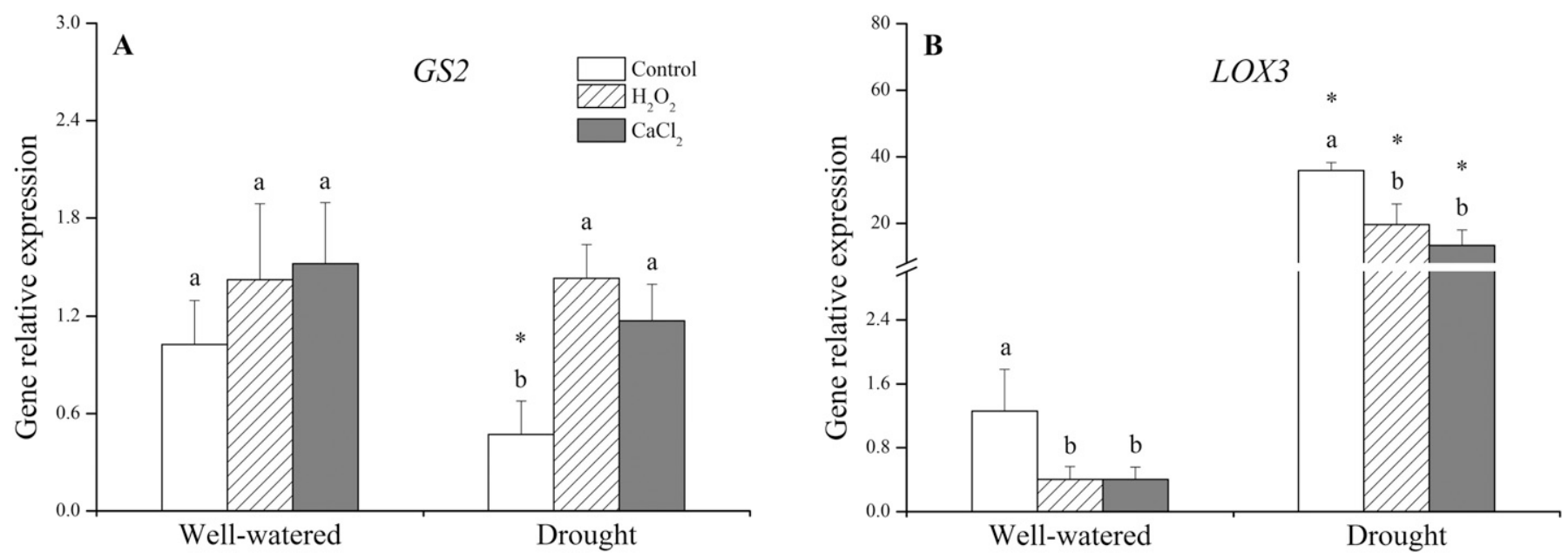

Fig. 8. Effects of $\mathrm{H}_{2} \mathrm{O}_{2}$ and $\mathrm{CaCl}_{2}$ on genes encoding stress-related proteins (A) glutamine synthetase 2 (GS2) and (B) lipoxygenase 3 (LOX3) in creeping bentgrass under well-watered and drought condition for $20 \mathrm{~d}$. Vertical bars indicate \pm SE $(\mathrm{n}=4)$. Different letters above columns indicate significant differences among control, $\mathrm{H}_{2} \mathrm{O}_{2}$, and $\mathrm{Ca}$ treatment under a given condition (well-watered or drought); asterisk $\left({ }^{*}\right)$ indicates significant difference for one particular treatment (control, $\mathrm{H}_{2} \mathrm{O}_{2}$, or $\mathrm{Ca}$ ) between well-watered and drought condition. 
Drought

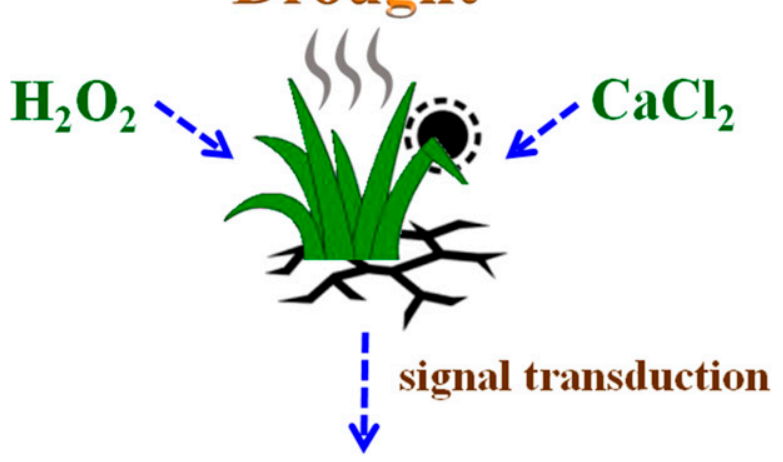

14-3-3

CDPK26 MAPK1

transcription factor

WRKY75 MYB13

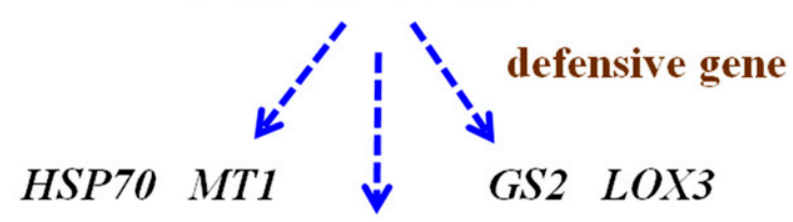

SOD CAT GR
MDHAR DHAR

physiological response

\section{Stress tolerance}

Fig. 9. Proposed pathways regulated by $\mathrm{H}_{2} \mathrm{O}_{2}$ and $\mathrm{CaCl}_{2}$ contributing to drought tolerance in creeping bentgrass.

saturated fatty acids catalyzed by lipoxygenase (LOX) also causes membrane lipid peroxidation in plants (Ángel-Coronel et al., 2017; Fukuchi-Mizutani et al., 2000; Siedow, 1991). The suppression of LOX activity by silicon has been associated with mitigation of drought-induced oxidative damages in eight chickpea (Cicer arietinum) cultivars (Gunes et al., 2007). In this study, the transcript level of $L O X 3$ was significantly down-regulated by $\mathrm{H}_{2} \mathrm{O}_{2}$ and $\mathrm{Ca}$ in creeping bentgrass under drought stress, indicating that $\mathrm{H}_{2} \mathrm{O}_{2}$ and $\mathrm{Ca}$ could also alleviate oxidative damages involving LOX.

Abiotic stress causes excessive $\mathrm{NH}_{3}-\mathrm{NH}_{4}{ }^{+}$accumulation that is toxic to plants (Rare, 1990; Yu et al., 2005). Glutamine synthetase (GS) is responsible for amine assimilation and catalyzing the synthesis of glutamine under environmental stress. It helps plants to detoxify the excess free ammonia in cells in response to abiotic stress, leading to effective alleviation of stress-caused excessive $\mathrm{NH}_{3}-\mathrm{NH}_{4}{ }^{+}$accumulation (Guan et al., 2016; Yu et al., 2005). In this study, both $\mathrm{H}_{2} \mathrm{O}_{2}$ and $\mathrm{Ca}$ significantly up-regulated $G S 2$ expression under drought stress, which implies that $\mathrm{H}_{2} \mathrm{O}_{2}$ and $\mathrm{Ca}$ could regulate amine assimilation in plants suffering from drought stress.

\section{Conclusions}

In summary, the application of $\mathrm{H}_{2} \mathrm{O}_{2}$ and $\mathrm{Ca}$ significantly enhanced drought tolerance of creeping bentgrass, as demonstrated by improved turf quality, leaf RWC, Chl content, photochemical efficiency, and cell membrane stability under drought stress. The positive effects of $\mathrm{H}_{2} \mathrm{O}_{2}$ and $\mathrm{Ca}$ on drought tolerance could be associated with the activation of $\mathrm{Ca}$ signaling pathways and transcript factors (14-3-3, CDPK26, MAPK1, $W R K Y 75$, and MYB13), antioxidant defense (SOD, CAT, GR, $M D H A R$, and $D H A R$ ) alleviating oxidative damage, and stress protection genes (HSP70, MT1, and GS2) assisting protein folding and translocation, and maintaining nitrogen metabolism under a prolonged drought stress (Fig. 9).

\section{Literature Cited}

Arnon, D.I. 1949. Copper enzymes in isolated chloroplasts. Polyphenoloxidase in Beta vulgaris. Plant Physiol. 24:1-13.

Ángel-Coronel, O.A.D., E. León-García, G. Vela-Gutiérrez, J.O. RojasReyes, M.Á. Gómez-Lim, and H.S. García. 2017. Lipoxygenase activity associated to fruit ripening and senescence in chayote (Sechium edule Jacq. Sw. cv. "virens levis"). J. Food Biochem. 42:e12438.

Anil, V.S. and K.S. Rao. 2001. Calcium-mediated signal transduction in plants: A perspective on the role of $\mathrm{Ca}^{2+}$ and CDPKs during early plant development. J. Plant Physiol. 158:1237-1256.

Apel, K. and H. Hirt. 2004. Reactive oxygen species: Metabolism, oxidative stress, and signal transduction. Annu. Rev. Plant Biol. 55:373-399.

Barrs, H. and P. Weatherley. 1962. A re-examination of the relative turgidity technique for estimating water deficits in leaves. Austral. J. Biol. Sci. 15:413-428.

Beard, J.B. 2001. Turf management for golf courses. 2nd ed. Ann Arbor Press, Chelsea, MI.

Bhargava, S. and K. Sawant. 2013. Drought stress adaptation: Metabolic adjustment and regulation of gene expression. Plant Breed. 132:21-32.

Blum, A. and A. Ebercon. 1981. Cell membrane stability as a measure of drought and heat tolerance in wheat. Crop Sci. 21:43-47.

Boudsocq, M. and J. Sheen. 2013. CDPKs in immune and stress signaling. Trends Plant Sci. 18:30-40.

Bush, D.S. 1995. Calcium regulation in plant cells and its role in signaling. Annu. Rev. Plant Biol. 46:95-122.

Camello-Almaraz, C., P.J. Gomez-Pinilla, M.J. Pozo, and P.J. Camello. 2006. Mitochondrial reactive oxygen species and $\mathrm{Ca}^{2+}$ signaling. Amer. J. Physiol. Cell Physiol. 291:C1082-C1088.

Chen, F., Q. Li, L. Sun, and Z. He. 2006. The rice 14-3-3 gene family and its involvement in responses to biotic and abiotic stress. DNA Res. 13:53-63.

Chen, L., Y. Song, S. Li, L. Zhang, C. Zou, and D. Yu. 2012. The role of WRKY transcription factors in plant abiotic stresses. Gene Regul. Mech. 1819:120-128.

Chen, Z., H. Fu, D. Liu, P.F.L. Chang, M. Narasimhan, R. Ferl, P.M. Hasegawa, and R.A. Bressan. 1994. A NaCl-regulated plant gene encoding a brain protein homolog that activates ADP ribosyltransferase and inhibits protein kinase C. Plant J. 6:729-740.

Cho, E.K. and C.B. Hong. 2006. Over-expression of tobacco NtHSP70-1 contributes to drought-stress tolerance in plants. Plant Cell Rep. 25:349-358.

Comparot, S., G. Lingiah, and T. Martin. 2003. Function and specificity of 14-3-3 proteins in the regulation of carbohydrate and nitrogen metabolism. J. Exp. Bot. 54:595-604.

Danquah, A., A. de Zelicourt, J. Colcombet, and H. Hirt. 2014. The role of ABA and MAPK signaling pathways in plant abiotic stress responses. Biotechnol. Adv. 32:40-52.

Dortje, G., L. Ines, and Y. Oksoon. 2011. Plant tolerance to drought and salinity: Stress regulating transcription factors and their func- 
tional significance in the cellular transcriptional network. Plant Cell Rep. 30:1383-1391.

Ermak, G. and K.J. Davies. 2002. Calcium and oxidative stress: From cell signaling to cell death. Mol. Immunol. 38:713-721.

$\mathrm{Fu}, \mathrm{D}$. and M. Lu. 2007. The structural basis of water permeation and proton exclusion in aquaporins. Mol. Membr. Biol. 24:366-374.

Fukuchi-Mizutani, M., K. Ishiguro, T. Nakayama, Y. Utsunomiya, Y. Tanaka, T. Kusumi, and T. Ueda. 2000. Molecular and functional characterization of a rose lipoxygenase cDNA related to flower senescence. Plant Sci. 160:129-137.

Gilroy, S., N. Suzuki, G. Miller, W.G. Choi, M. Toyota, A.R. Devireddy, and R. Mittler. 2014. A tidal wave of signals: Calcium and ROS at the forefront of rapid systemic signaling. Trends Plant Sci. 19:623-630.

Guan, M., T. de Bang, C. Pedersen, and J.K. Schjoerring. 2016. Cytosolic glutamine synthetase Gln1; 2 is the main isozyme contributing to GS1 activity in arabidopsis shoots and can be upregulated to relieve ammonium toxicity. Plant Physiol. 171:19211933.

Gunes, A., D.J. Pilbeam, A. Inal, E.G. Bagci, and S. Coban. 2007. Influence of silicon on antioxidant mechanisms and lipid peroxidation in chickpea (Cicer arietinum L.) cultivars under drought stress. J. Plant Interact. 2:105-113.

Hara, M. 2010. The multifunctionality of dehydrins: An overview. Plant Signal. Behav. 5:503-508.

Hasanuzzaman, M., M.A. Hossain, J.A.T. da Silva, and M. Fujita. 2012. Plant response and tolerance to abiotic oxidative stress: Antioxidant defense is a key factor, p. 261-315. In: B. Venkateswarlu, A.K. Shanker, C. Shanker, and M. Maheswari (eds.). Crop stress and its management: Perspectives and strategies. Springer, Berlin, Germany.

Hogland, C.R. and D.I. Arnon. 1950. The solution culture method for growing plants without soil. Calif. Agr. Exp. Circ. 347.

Hosseini, S.A., E. Réthoré, S. Pluchon, N. Ali, B. Billiot, and J.C. Yvin. 2019. Calcium application enhances drought stress tolerance in sugar beet and promotes plant biomass and beetroot sucrose concentration. Intl. J. Mol. Sci. 20:3777.

Ishibashi, Y., H. Yamaguchi, T. Yuasa, M. Iwaya-Inoue, S. Arima, and S.H. Zheng. 2011. Hydrogen peroxide spraying alleviates drought stress in soybean plants. J. Plant Physiol. 168:1562-1567.

Jarillo, J.A., J. Capel, A. Leyva, J.M. Martínez-Zapater, and J. Salinas. 1994. Two related low-temperature-inducible genes of arabidopsis encode proteins showing high homology to 14-3-3 proteins, a family of putative kinase regulators. Plant Mol. Biol. 25:693-704.

Jiang, Y. and B. Huang. 2001. Effects of calcium on antioxidant activities and water relations associated with heat tolerance in two cool-season grasses. J. Exp. Bot. 52:341-349.

Larkindale, J. and B. Huang. 2004. Thermotolerance and antioxidant systems in Agrostis stolonifera: Involvement of salicylic acid, abscisic acid, calcium, hydrogen peroxide, and ethylene. J. Plant Physiol. 161:405-413.

Larkindale, J. and B. Huang. 2005. Effects of abscisic acid, salicylic acid, ethylene and hydrogen peroxide in thermotolerance and recovery for creeping bentgrass. Plant Growth Regulat. 47:17-28.

Li, Z., Y. Zhang, D. Peng, X. Wang, Y. Peng, X. He, X. Zhang, X. Ma, L. Huang, and Y. Yan. 2015. Polyamine regulates tolerance to water stress in leaves of white clover associated with antioxidant defense and dehydrin genes via involvement in calcium messenger system and hydrogen peroxide signaling. Front. Physiol. 6:280.

Li, Z., Y. Peng, and B. Huang. 2016a. Physiological effects of $\gamma$-aminobutyric acid application on improving heat and drought tolerance in creeping bentgrass. J. Amer. Soc. Hort. Sci. 141:76-84.

Li, Z., Y. Zhang, X. Zhang, Y. Peng, E. Merewitz, X. Ma, L. Huang, and Y. Yan. 2016b. The alterations of endogenous polyamines and phytohormones induced by exogenous application of spermidine regulate antioxidant metabolism, metallothionein and relevant genes conferring drought tolerance in white clover. Environ. Exp. Bot. 124:22-38.
Liao, W.B., G.B. Huang, J.H. Yu, and M.L. Zhang. 2012. Nitric oxide and hydrogen peroxide alleviate drought stress in marigold explants and promote its adventitious root development. Plant Physiol. Biochem. 58:6-15.

Lu, S., W. Su, H. Li, and Z. Guo. 2009. Abscisic acid improves drought tolerance of triploid bermudagrass and involves $\mathrm{H}_{2} \mathrm{O}_{2}$ - and NOinduced antioxidant enzyme activities. Plant Physiol. Biochem. 47:132-138.

Naeem, M., M.S. Naeem, R. Ahmad, M.Z. Ihsan, M.Y. Ashraf, Y. Hussain, and S. Fahad. 2018. Foliar calcium spray confers drought stress tolerance in maize via modulation of plant growth, water relations, proline content and hydrogen peroxide activity. Arch. Agron. Soil Sci. 64:116-131.

Nayyar, H. 2003. Accumulation of osmolytes and osmotic adjustment in water-stressed wheat (Triticum aestivum) and maize (Zea mays) as affected by calcium and its antagonists. Environ. Exp. Bot. 50:253264.

Neill, S.J., R. Desikan, A. Clarke, R.D. Hurst, and J.T. Hancock. 2002. Hydrogen peroxide and nitric oxide as signalling molecules in plants. J. Exp. Bot. 53:1237-1247.

Pei, Z.M., Y. Murata, G. Benning, S. Thomine, B. Klüsener, G.J. Allen, E. Grill, and J.I. Schroeder. 2000. Calcium channels activated by hydrogen peroxide mediate abscisic acid signalling in guard cells. Nature 406:731-734.

Rare, E. 1990. Stress physiology: The functional significance of the accumulation of nitrogen-containing compounds. J. Hort. Sci. 65:231-243.

Ray, P.D., B.W. Huang, and Y. Tsuji. 2012. Reactive oxygen species (ROS) homeostasis and redox regulation in cellular signaling. Cell. Signal. 24:981-990.

Reddy, A.S., G.S. Ali, H. Celesnik, and I.S. Day. 2011. Coping with stresses: Roles of calcium- and calcium/calmodulin-regulated gene expression. Plant Cell 23:2010-2032.

Roberts, M.R., J. Salinas, and D.B. Collinge. 2002. 14-3-3 proteins and the response to abiotic and biotic stress. Plant Mol. Biol. 50:10311039.

Ruttkay-Nedecky, B., L. Nejdl, J. Gumulec, O. Zitka, M. Masarik, T. Eckschlager, M. Stiborova, V. Adam, and R. Kizek. 2013. The role of metallothionein in oxidative stress. Intl. J. Mol. Sci. 14:6044-6066.

Sabehat, A., D. Weiss, and S. Lurie. 1998. Heat-shock proteins and cross-tolerance in plants. Physiol. Plant. 103:437-441.

Shanker, A.K., M. Maheswari, S. Yadav, S. Desai, D. Bhanu, N.B. Attal, and B. Venkateswarlu. 2014. Drought stress responses in crops. Funct. Integr. Genomics 14:11-22.

Shinozaki, K. and K. Yamaguchi-Shinozaki. 2007. Gene networks involved in drought stress response and tolerance. J. Exp. Bot. 58:221-227.

Siedow, J.N. 1991. Plant lipoxygenase: Structure and function. Annu. Rev. Plant Physiol. 42:145-188.

Singh, K., R.C. Foley, and L. Oñatesánchez. 2002. Transcription factors in plant defense and stress responses. Curr. Opin. Plant Biol. 5:430-436.

Sørensen, J.G., T.N. Kristensen, and V. Loeschcke. 2003. The evolutionary and ecological role of heat shock proteins. Ecol. Lett. 6:1025-1037.

Suzuki, N., S. Koussevitzky, R. Mittler, and G. Miller. 2012. ROS and redox signalling in the response of plants to abiotic stress. Plant Cell Environ. 35:259-270.

Todaka, D., K. Shinozaki, and K. Yamaguchi-Shinozaki. 2015. Recent advances in the dissection of drought-stress regulatory networks and strategies for development of drought-tolerant transgenic rice plants. Front. Plant Sci. 6:84.

Wang, C.Q. 2010. Exogenous calcium alters activities of antioxidant enzymes in Trifolium repens L. leaves under peg-induced water deficit. J. Plant Nutr. 33:1874-1885.

Wang, W., B. Vinocur, O. Shoseyov, and A. Altman. 2004. Role of plant heat-shock proteins and molecular chaperones in the abiotic stress response. Trends Plant Sci. 9:244-252. 
Xia, X.J., Y.J. Wang, Y.H. Zhou, Y. Tao, W.H. Mao, K. Shi, T. Asami, Z. Chen, and J.Q. Yu. 2009. Reactive oxygen species are involved in brassinosteroid-induced stress tolerance in cucumber. Plant Physiol. 150:801-814.

$\mathrm{Xu}$, W.F. and W.M. Shi. 2007. Mechanisms of salt tolerance in transgenic Arabidopsis thaliana constitutively overexpressing the tomato 14-3-3 protein TFT7. Plant Soil 301:17-28.

Xu, Y., X. Li, J. Lin, Z. Wang, Q. Yang, and Y. Chang. 2015. Transcriptome sequencing and analysis of major genes involved in calcium signaling pathways in pear plants (Pyrus calleryana Decne.). BMC Genomics 16:738.

Yan, J., C. He, J. Wang, Z. Mao, S.A. Holaday, R.D. Allen, and H. Zhang. 2004. Overexpression of the arabidopsis 14-3-3 protein GF14 $\lambda$ in cotton leads to a "stay-green" phenotype and improves stress tolerance under moderate drought conditions. Plant Cell Physiol. 45:1007-1014.

Yang, Z., Y. Wu, Y. Li, H.Q. Ling, and C. Chu. 2009. OsMT1a, a type 1 metallothionein, plays the pivotal role in zinc homeostasis and drought tolerance in rice. Plant Mol. Biol. 70:219-229.

You, J., W. Zong, X. Li, J. Ning, H. Hu, X. Li, J. Xiao, and L. Xiong. 2013. The SNAC1-targeted gene OSSRO1c modulates stomatal closure and oxidative stress tolerance by regulating hydrogen peroxide in rice. J. Exp. Bot. 64:569-583.

$\mathrm{Yu}$, B.P. 1994. Cellular defenses against damage from reactive oxygen species. Physiol. Rev. 74:139-162.

Yu, C.C., K.T. Hung, and C.H. Kao. 2005. Nitric oxide reduces $\mathrm{Cu}$ toxicity and $\mathrm{Cu}$-induced $\mathrm{NH}_{4}{ }^{+}$accumulation in rice leaves. J. Plant Physiol. 162:1319-1330. 